WMJ (Warmadewa Medical Journal), Vol. 6 No. 2 November 2021, Hal. 37-45

\title{
Evaluation of the Anthelminthic Efficacy of Albendazole as a Mass Drug Administration in Elementary School in Klungkung, Bali, Indonesia
}

\author{
Putu Indah Budi Apsari ${ }^{1}$, Pande Ayu Naya Kasih Permatananda ${ }^{2}$, I Nyoman \\ Supadma $^{3}$, Kadek Swastika ${ }^{4}$ \\ ${ }^{1}$ Department of Parasitology, Fakultas Kedokteran dan ilmu Kesehatan, Universitas Warmadewa \\ ${ }^{2}$ Department of Pharmacology, Fakultas Kedokteran dan ilmu Kesehatan, Universitas Warmadewa, \\ ${ }^{3}$ Child Health Department of Famili Husada Hospital, Gianyar, Bali \\ ${ }^{4}$ Department of Parasitology, Faculty of Medicine, Universitas Udayana \\ Email ${ }^{1}$ :putuindah51@yahoo.com
}

\begin{abstract}
Soil transmitted helminthiasis still remains problem among tropic and subtropics developing countries worldwide. Contribute to more than a billion morbidities of people from children to adults. Children are the most affected population by this infection. This study aims to evaluate mass drug anthelminthic therapy of albendazole in school and preschool children. A cross sectional study recruited preschool and school-age children as subject of this research. During the period of May-July 2020, fecal samples were collected one month after albendazole treatment and examined by Kato kats technique. Total 130 samples were examined, and it was found that only $1(0.007 \%)$ was positive for Trichuris trichiura. Accordingly, we can conclude that Albendazole is effective for treating Soil transmitted helminthiasis in preschool and school-age children.
\end{abstract}

Keyword: anthelminthic, albendazole, school, children

\section{Abstrak}

[Evaluasi Efikasi Antelmintik Albendazol Sebagai Obat Masal di Sekolah Dasar di Klungkung, Bali, Indonesia ]

Infeksi cacing yang ditularkan melalui tanah masih menjadi masalah di negara-negara berkembang terutama di negara tropis dan subtropis di seluruh dunia. Lebih dari satu miliar kasus pada anak-anak hingga orang dewasa. Anak-anak adalah populasi yang paling terpengaruh oleh infeksi ini. Penelitian ini bertujuan untuk mengevaluasi terapi obat cacing masal menggunakan albendazol pada anak usia sekolah. Penelitian cross sectional ini merekrut anak-anak usia sekolah sebagai subjek penelitian. Selama periode Mei-Juli 2020, sampel tinja dikumpulkan satu bulan setelah pengobatan albendazol dan diperiksa dengan teknik Kato kats. Sebanyak 130 sampel diperiksa, dan ditemukan hanya $1(0,007 \%)$ yang positif Trichuris trichiura. Dengan demikian, kita dapat menyimpulkan bahwa Albendazole efektif untuk mengobati kecacingan yang ditularkan melalui tanah pada anak-anak usia sekolah.

Kata Kunci: Antelmintik, Albendazole, Sekolah, Anak-anak

\section{INTRODUCTION}

Soil Transmitted Helminths (STH) are a group of parasitic nematodes that cause infection in humans through contact with parasitic eggs or larvae that develop in warm and moist soils ${ }^{1}$. STH infection is still a problem in endemic areas in various parts of the world, especially in developing countries with poor environmental sanita- tion and personal hygiene $e^{2,3}$. According to WHO in 2017 , more than 1.5 billion people or $24 \%$ of the total world population were infected by STH. Infections are spread across the tropics and subtropics, including Indonesia, with the highest number found in sub-Saharan regions, Africa, America, China and Asia. The STH species that most commonly infect humans 
are Ascaris lumbricoides (roundworms), Trichuris trichiura (whipworms) and hookworms (Ancylostoma duodenale and Necator americanus $)^{4}$.

In May 2001, preventive chemotherapy was suggested by the World Health Assembly resolution WHA54.19 to address the urgency of morbidity caused by STHs infection through regular administration of anthelminthic drugs ${ }^{5,6}$. The target was that $75 \%$ of school-age children and other populations at risk should receive anthelminthic treatment in $2010^{7}$. Four anthelminthic drugs are currently included in the list of essential drugs for dealing with STH infections: albendazole, mebendazole, levamisole, and pyrantel pamoate ${ }^{8}$. The deworming program aimed to deliver treatment against Soil Transmitted Helminths for 640 million people by $2016^{9}$. The acceleration of the progress of this program was supported by the large number donations of benzimidazole type of drugs: albendazole and mebendazole ${ }^{10}$. These two benzimidazole drugs have some limitations. First, their effectiveness is low against Trichuris trichiura infection, and varies in fighting Hookworm. Second, there is an alarming risk of possible parasitic resistance to these two drugs because of their frequent and extensive use ${ }^{11,12}$.

Some studies have suggested that all anthelminthic drugs are not effective against $T$. trichiura infection ${ }^{13,14}$. Polymorphism in the b-tubulin codon 200 gene in Albendazole-treated T. trichiura has been considered a resistance phenomenon ${ }^{15,16}$. In Indonesia, in accordance with the Minister of Health's Regulation of the Republic of Indonesia number 15 of 2017 concerning Handling of Worms, a mass treatment program for worms with several types of drugs has been launched, one of which that is used on a large scale is Albendazole ${ }^{17}$. Still, the mass treatment carried out by the government has not eradicated the infection completely. In fact, STH infections are still found in some areas ${ }^{18,19}$. Until now, there has never been an evaluation of Albendazole mass treatment for worm disease. The purpose of this study is to evaluate the effectiveness of mass treatment using Albendazole ${ }^{20}$.

\section{METHOD}

This study design was a crosssectional analytic study. The stool of the elementary school students who had been given Albendazole treatment of $10 \mathrm{mg} / \mathrm{kg}$ body weight by the Primary Healthcare Center (Puskesmas) were examined at day $21^{\text {th }}$ after administration of the drug using the Kato-Katz method ${ }^{21}$. The cure rate were assessed by the percentage of children who are positively infected divided by the total number of children given therapy. Infections were classified according to worm species ${ }^{22}$.

This research was conducted in Gelgel Village, Klungkung Regency during a period of May to July 2020. The samples of this study were $1^{\text {st }}$ to $4^{\text {th }}$ grade elementary school students, who had no previous disease history, and were not currently in the treatment of worms. Elementary students who refused to take the worm medicine that were given or who did not take a stool examination on day 21 , or those who refused to participate in this study were excluded.

Worm eggs were examined using the Kato-Katz quantitative method ${ }^{23}$. The total number of worm eggs is the number of worm eggs obtained multiplied by 24 , which equals to the number of worm eggs in 1 gram of stool ${ }^{24}$. All procedures in this study were approved by the Ethics Committee of Udayana University/ Sanglah Central Hospital Denpasar, Bali, ethical clearance number 789/ UN14.2.2.VII.14/LT/2020.

All demographic data were translated into frequency tables and presentations.

\section{RESULTS}

A total of 250 research subjects consisted of elementary school students and toddlers were recruited as samples, and as many as 140 subjects have collected stool samples and completed questionnaires with the consent of their parents. Stool samples were then examined in the laboratory by the Kato-katz method and found 


\section{WMJ (Warmadewa Medical Journal), Vol. 6 No. 2, November 2021, Hal. 39}

only one positive sample that was infected with Trichuris trichiura, while the remaining 139 were negative for STH infections. Most of the research subjects were male 75 $(53.6 \%)$; based on the family income, most of them earned less than 250 thousand with the main occupation of parents mostly in the private sector and farming, considering that farmers are a profession with uncertain income that is dependent to yield. The majority of parents were high school graduates, but there were some who only went to elementary school, and some did not even receive any formal schooling. Characteristics of research subjects are described in Table 1.

Table 1 Characteristics of Research Subjects

\begin{tabular}{ll}
\hline Characteristics & N (\%)
\end{tabular}

\section{Infection status}

None

Yes

\section{Gender}

Male

Female

Family Income

$<250 \mathrm{k}$ IDR

250-500 k IDR

$>1 \mathrm{k}$ IDR

\section{Parent's Level of education}

Bachelor

Elementary school

Senior high school

Junior high school

No school

\section{Parent's profession}

Labour

Farmer

Government employees

Private bussiness 
Table 2 Differences in characteristics, knowledge, attitudes and behaviors based on gender

\begin{tabular}{|c|c|c|}
\hline \multirow[t]{2}{*}{ Variable } & \multicolumn{2}{|c|}{ Gender n (\%) } \\
\hline & Male & Female \\
\hline \multicolumn{3}{|l|}{ Family Income } \\
\hline $1000 \mathrm{k}$ IDR & $31(58.5)$ & $22(41.5)$ \\
\hline $250 \mathrm{k}$ IDR & $23(42.6)$ & $31(57.4)$ \\
\hline $500 \mathrm{k}$ IDR & $21(63.6)$ & $12(36.4)$ \\
\hline \multicolumn{3}{|l|}{ Parent's level Education } \\
\hline Bachelor & $7(53.8)$ & $6(42.6)$ \\
\hline Elementary school & $4(40)$ & $6(60)$ \\
\hline Senior high school & $54(55.7)$ & $43(44.3)$ \\
\hline Junior high school & $8(41.7)$ & $9(52.9)$ \\
\hline No educational level & $2(66.7)$ & $1(33.3)$ \\
\hline \multicolumn{3}{|l|}{ Father Profession } \\
\hline Labour & $1(50)$ & $1(50)$ \\
\hline Farmer & $22(46.8)$ & $25(53.2)$ \\
\hline Government employees & $3(60)$ & $2(40)$ \\
\hline Private business & $49(57)$ & $37(43)$ \\
\hline \multicolumn{3}{|l|}{ Playing ground } \\
\hline No & $63(53.4)$ & $55(46.6)$ \\
\hline Yes & $12(54.5)$ & $10(45.5)$ \\
\hline \multicolumn{3}{|c|}{$\begin{array}{l}\text { Washing hand after defeca- } \\
\text { tion }\end{array}$} \\
\hline No & $2(40)$ & $3(60)$ \\
\hline Yes & $73(54.1)$ & $62(45.9)$ \\
\hline \multicolumn{3}{|l|}{ Source of water } \\
\hline Mineral water & $12(52.2)$ & $11(47.8)$ \\
\hline Tap water & $62(53.4)$ & $54(46.6)$ \\
\hline Boreholes & $1(100)$ & $0(0)$ \\
\hline \multicolumn{3}{|c|}{ Wasing hand before eating } \\
\hline No & $0(0)$ & $2(100)$ \\
\hline Yes & $75(54.3)$ & $63(45.7)$ \\
\hline \multicolumn{3}{|l|}{ Eating raw vegetables } \\
\hline No & $72(54.5)$ & $60(45.5)$ \\
\hline Yes & $3(37.5)$ & $5(62.5)$ \\
\hline \multicolumn{3}{|l|}{ Using footwear } \\
\hline Yes & $57(54.3)$ & $48(45.7)$ \\
\hline No & $18(51.4)$ & $17(48.6)$ \\
\hline \multicolumn{3}{|l|}{ Site of Defecation } \\
\hline Toilet & $68(52.1)$ & $64(47.9)$ \\
\hline River & $7(87.5)$ & $1(12.5)$ \\
\hline
\end{tabular}


Table 3 Differences in knowledge, attitudes and behaviors based on gender

\begin{tabular}{lcc}
\hline Variable & Gender $\mathbf{n}(\mathbf{\%})$ & \\
\hline History of helminthiases & Female \\
No & $66(55.5)$ & $53(44.5)$ \\
Yes & $9(42.9)$ & $12(57.1)$ \\
Family history of helminthiases & & \\
No & $57(53.3)$ & $50(46.7)$ \\
Yes & $18(54.5)$ & $15(45.5)$ \\
Routine consumption of anthel- & & \\
minthic drugs & & $18(38.3)$ \\
No & $29(61.7)$ & $47(50.5)$ \\
Yes & $46(49.5)$ & \\
Source of anthelminthic drugs & & $3(27.7)$ \\
Pharmacy & $8(72.7)$ & $23(48.8)$ \\
Primary Health care & $22(51.2)$ & $32(50)$ \\
Integrated health care & $32(50)$ & $0(0)$ \\
School & $4(100)$ & $4(33.3)$ \\
Other sources & $8(66.7)$ & $2(66.7)$ \\
None & $1(33.3)$ & $565(46.8)$ \\
Consume unhealth food & & $0(0)$ \\
No & $52(50)$ & $52(50)$ \\
Yes & $23(63.9)$ & $13(36.1)$ \\
Infection status & & \\
No & $74(53.2)$ & \\
Yes & $1(100)$ & \\
\hline & & \\
\hline
\end{tabular}

With the 9-year compulsory school program that is free of charge by the government, most of the population can at least finish up to junior high. The level of knowledge, attitudes and behavior of the research subjects and the subjects' parents were also analyzed. As many as $22(15.7 \%)$ subjects often play in the fields, this behavior is associated with the risk of contact with the soil where the worm can grow optimally to ripen its life stage so that it can infect humans both through the oral route and skin penetration. Most subjects have used a good source of water (boiled water) before consumption, the use of water sources that are not hygienic and not well- boiled also risks increasing the possibility of infection by parasites, but in this case the subject have good standard in water consumption. Other clean and healthy life behaviors have also been mostly carried out well by the subjects and their parents such as washing hands before eating, washing hands after bowel movements, defecating in the toilet, using sandals or footwear, not eating vegetables that are still raw and uncooked, and not snacking carelessly. ${ }^{29,30}$

\section{DISCUSSION}

According to study conducted by Sinniah et al, 2014, the prevalence of STH infection in rural area after antihelmintic 
mass drugs admission was very low. We found only one sample positive for T.trichiura. the antihelmintic drugs mass admission was successfully in decreasing of positive subject. Reinfection of STH also can be prevent by keeping hygiene and sanitation of environment. Promoting and suggesting people to do healthy behavior and build infrastructure like safe and clean water source is needed to prevent STH infection $8,25,27,28$

Analysis of attitude, most of the subjects never had worms, but there were $21(15 \%)$ subjects who had suffered from intestinal worms, this might be influenced by the environment and family where as many as $33(23.6 \%)$ family of the subjects had suffered from intestinal worms, transmission from adults to children is very possible in this case. A total of $93(66.4 \%)$ subjects routinely took worm medication but there were $47(33.6 \%)$ who did not routinely take worm medication every 6 months, various things could affect the likelihood of children not routinely taking worm medication, first the program provided by the puskesmas (local health center) did not cover the total population elementary school students, secondly, when the worm medicine was distributed students might not attend the school, thirdly, parents were not given knowledge about how to administer the worm medicine, fourth, children were afraid to take medicine because of previous experiences of taking medicine that tastes bitter. One hundred and ten children got worm medicine from the Puskesmas (Primary Healthcare Center) and Posyandu (pos pelayanan terpadu) (integrated healthcare center), but there were 23 who bought their own medicine at the pharmacy and other places that sold worm medicine, there were 3 children who did not get worm medicine or bought it themselves. Knowledge of helminthiasis was also analyzed, in this case it was found that most of the subjects and their parents did not know helminthiasis' mode of transmission, did not know the types of earthworms, and did not know how to prevent helminthiasis. This is likely due to the lack of socialization about helminthiasis because it is con- sidered a harmless disease, and lack of public understanding of helminthiasis. Furthermore, it is necessary to further educate the public about the importance of clean and healthy living behavior to break the chain of helminthiasis transmission.

\section{CONCLUSION}

Albendazole was still effective against soil transmitted helminth, except Trichuris trichiura. Further research must be conducted to explore the mechanism and parasite escape mechanism to avoid the effect of drugs and also host immune system. We suggest that the new combination of anthelminthic therapy or new drugs must be developed to treat Trichuris trichura infection.

\section{ACKNOLEDGEMENT}

This research was funded by $\mathrm{Ke}$ menterian Riset dan Teknologi Pendidikan Tinggi, Republik Indonesia, Faculty of Medicine and Health Sciences Warmadewa University.

\section{REFERENCE}

1. Apsari, P. I. B., Arwati, H.; Dachlan, Y. P. 2018. Correlation Of Eosinofil And Basophil Count With Intensity Of Soil Transmitted Helminth Infection Among Farmers In Bali. Iop Conference Series: Materials Science And Engineering, Volume 434, Issue 1, Pp. 012142 (2018).

2. Apsari PIB, Heny Arwati, Yoes Prijatna Dachlan. 2019. Correlation Of Total Ige Level And Intensity Of Infection Among Soil Transmitted Helminthiasis Farmers In Klungkung Regency, Bali, Indonesia. Folia Medica Indonesiana. Vol 55, No 2 (2019).

3. Apsari PIB, Anak agung gede Indraningrat, Heny Arwati, Yoesprijatna Dachlan2short Communication: Prevalence And Risk Factors Of Soil -Transmitted Helminth Infection Among Farmers In Gelgel Village, Klungkung District, Bali, Indonesia. Biodiversitas. Volume 21 Number 4 
Pp 1535-1540.

4. World Health Organization. 2017. World Health Organization. www.who.int/intestinal_worms (Accessed 16 August 2017).

5. World Health Organization. 2015. Pharmacopoeial standards: Ensuring the efficacy of a deworming medicine: albendazole chewable tablets. WHO Drug Information Vol. 29, No. 4.

6. Keiser, L ., Utzinger, J. Efficacy of Current Drugs Against SoilTransmitted Helminth InfectionsSystematic Review and Metaanalysis. JAMA, April 23/30, 2008-Vol 299, No. 16. pp 19371948

7. Keiser J, Utzinger J. 2010. The Drugs We Have and the Drugs We Need Against Major Helminth Infections. Advance in Parasitology. Vol. 73. ISSN 0065-308X, DOI: 10.1016/ S0065-308X(10)73008-6.

8. Albonico $\mathrm{M}$, Allen $\mathrm{H}$, Chitsulo $\mathrm{L}$, Engels D, Gabrielli A-F, et al. (2008) Controlling Soil-Transmitted Helminthiasis in Pre-School-Age Children through Preventive Chemotherapy. PLoS Negl Trop Dis 2(3): e126. doi:10.1371/ journal.pntd.0000126

9. Moser, W., Schindler, C. \& Keiser, J. Efficacy of recommended drugs against soil transmitted helminths: systematic review and network metaanalysis. BMJ 2017;358:j4307 | doi: 10.1136/bmj.j4307

10. Moser, W. et al. Efficacy and safety of oxantel pamoate in school-aged children infected with Trichuris trichiura on Pemba Island, Tanzania : a parallel, randomised, controlled , dose-ranging study. Lancet Infect. Dis. 3099, 1-8 (2015).

11. Moser, W. et al. Articles Efficacy and tolerability of triple drug therapy with albendazole, pyrantel pamoate, and oxantel pamoate compared with albendazole plus oxantel pamoate, pyrantel pamoate plus oxantel pamoate, and mebendazole plus pyrantel pamoate and oxantel pamoate against hookworm infections in school-aged children in Laos : a randomised ,. Lancet Infect. Dis. 3099, 1-9 (2018).

12. Urbani C.,Albonico M. 2003. Anthelminthic drug safety and drug administration in the control of soiltransmitted helminthiasis in community campaigns. Acta Tropica. 86, 215-221. doi:10.1016/S0001-706X (03)00036-6

13. Becker SL, Harvy Joy Liwanag, Jedidiah S. Snyder, Oladele Akogun, Vicente Belizario, Matthew C. Freeman, Theresa W. Gyorkos, Rubina Imtiaz, Jennifer Keiser, Alejandro Krolewiecki, Bruno Levecke, Charles Mwandawiro, Rachel L. Pullan, David G. Addiss, Utzinger J. Toward the 2020 goal of soiltransmitted helminthiasis control and elimination. PLOS Neglected Tropical Diseases. https://doi.org/10.1371/ journal.pntd.0006606. 2018 1-17

14. Vercruysse J, Levecke B, and Roger Prichard. Human soil-transmitted helminths: implications of mass drug administration. Curr Opin Infect Dis 2012, 25:703 -708 Doi:10.1097/ QCO.0b013e328358993a

15. Palma A, Gabriela Matamoros, Denis Escobar, Ana Lourdes Sánchez and Gustavo Fontecha. Absence of mutations associated with resistance to benzimidazole in the beta-tubulin gene of Ascaris suum. Journal of the Brazilian Society of Tropical Medicine. Vol.:53:e20190155: 2020 doi: 10.1590/0037-8682-0155-2019

16. Hansen TVA, Stig M Thamsborg, Annette Olsen, Roger K Prichard and Peter Nejsum. Genetic variations in the beta-tubulin gene and the internal transcribed spacer 2 region of Trichuris species from man and baboons. Parasites \& Vectors 2013, 6:236 http:// www.parasitesandvectors.com/ content $/ 6 / 1 / 236$

17. Kementerian Kesehatan RI. Peraturan Menteri Kesehatan no 15 tahun 2017 tentang Pemberantasan 
kecacingan. Kementerian Kesehatan RI (2017).

18. Vercruysse J, Marco Albonico, Jerzy M. Behnke, Andrew C. Kotze , Roger K. Prichard, James S. McCarthy , Antonio Montresor , Bruno Levecke. Is anthelmintik resistance a concern for the control of human soil-transmitted helminths? International Journal for Parasitology: Drugs and Drug Resistance 1 (2011) 14-27.

19. Diawara, A., Halpenny, C. M. \& Churcher, T. S., 2013. Association between Response to Albendazole Treatment and b-Tubulin Genotype Frequencies in Soil-transmitted. PLOS Neglected Tropical Diseases, 7(5), pp. 1-11.

20. Rashwan, N., Scott, M. \& Prichard, R., 2017. Rapid Genotyping of $\beta$ tubulin Polymorphisms in Trichuris trichiura and Ascaris lumbricoides. PLOS Neglected Tropical Diseases, 11(1), pp. 1-18.

21. WHO, 1991. Basic Laboratory Method in Medical Parasitology. 1 ed. Geneva: World Health Organzation.

22. Matamoros G, Rueda MM, Rodríguez C, Gabrie JA, Canales M, Fontecha $G$ and Sanchez A. High Endemicity of Soil-Transmitted Helminths in a Population Frequently Exposed to Albendazole but No Evidence of Antiparasitic Resistance. Trop Med Infect Dis. 2019, 4, 73; doi:10.3390/tropicalmed4020073

23. Vercruysse J, Jerzy M. Behnke2, Marco Albonico3, Shaali Makame Ame3, Cé cile Angebault4, Jeffrey M. Bethony5, Dirk Engels6, Bertrand Guillard4, Nguyen Thi Viet Hoa7, Gagandeep Kang8, Deepthi Kattula8, Andrew C. Kotze9, James S. McCarthy10, Zeleke Mekonnen11, Antonio Montresor6, Maria Victoria Periago5, Laurentine Sumo12, Louis-Albert Tchuem Tchuente 12, Dang Thi Cam Thach7, Ahmed Zeynudin11, Bruno Levecke. Assessment of the Anthelmintik Effica- cy of Albendazole in School Children in Seven Countries Where SoilTransmitted Helminths Are Endemic. Plos Neg trop ds. March 2011. Volume 5. Issue 3, pp e948.

24. Hotez, P. J. et al. 2004. Chapter 24 Helminth Infections: SoilTransmitted Helminth Infections and Schistosomiasis. Disease Control Priorities in Developing Countries. Pp 467-482.

25. Sinniah B., Hassan AKR, Sabariah, I., Soe, MM, Ibrahim, Z., Ali, O. 2014 prevalence of Intestinal parasitic Infection among communities living in different habitats and its comparison with one hundred and one studies conducted over the past 42 years (1970-2013) in Malaysia. Tropical Biomedicine. Vol 31 (2): pp 190-206.

26. Abraham, D., Saravanakumar Puthupalayam Kaliappan1, Judd L. Walson2,3 \& Sitara Swarna Rao Ajjampur. Intervention strategies to reduce the burden of soil-transmitted helminths in India. Indian J Med Res 147, June 2018, pp 533-544 DOI: 10.4103/ijmr.IJMR_881_18

27. Speich, B. et al. Efficacy and Safety of Nitazoxanide, Albendazole, and Nitazoxanide-Albendazole against Trichuris trichiura Infection : A Randomized Controlled Trial. 6, (2012). King, C. H., Zhou, X., Jia, T. \& Melville, S. Soil-Transmitted Helminth Reinfection after Drug Treatment, A Systematic Review and Meta-Analysis. 6, (2012). PLoS Negl Trop Dis 6(6): e1685. doi:10.1371/ journal.pntd.0001685.

28. Betson, M. Nejsum, Peter; Bendall, Richard P.; Deb, Rinki M.; Stothard, J. Russell., 2014. Molecular Epidemiology of Ascariasis: A Global Perspective on the Transmission Dynamics of Ascaris in People and Pigs. The Journal of Infectious Diseases, Volume 210, pp. 932-941.

29. Jia TW, Melville S, Utzinger J, King CH, Zhou XN. 2012 SoilTransmitted Helminth Reinfection 
WMJ (Warmadewa Medical Journal), Vol. 6 No. 2, November 2021, Hal. 45

after Drug Treatment: A Systematic Review and Meta-Analysis. PLoS Negl Trop Dis 6(5): e1621. doi:10.1371/journal.pntd.0001621

30. Mutomboa PN, Nicola W.Y. Mana, Peter Nejsumc, Robert Ricketsond, Catherine A. Gordone, Gemma Robertsonf, Archie C.A. Clementsg,
Nathalie Chacón-Fonsecah, Veeranoot Nissapatorni,j, Joanne P. Websterk, Mary-Louise McLawsa. Diagnosis and drug resistance of human soil-transmitted helminth infections: A public health perspective. Advances in Parasitology, Volume 104. 2019 Elsevier Ltd 